\title{
THE RISE OF A MIDDLE CLASS AND THE CHANGING CONCEPT OP BQUTTY IN INDONESIA: AN INTERPRETATION
}

\author{
H. W. Dick
}

\section{Introduction 1}

Continuities in values and institutions in themselves reveal nothing about the direction of social change, although they may provide some indication of its speed. The significance of traditional values and institutions lies in their interaction with new elements. To understand social change it is therefore upon the new elements that one must focus. To do otherwise is like running backwards, being able to see where one has come from but not where one is going.

This article argues that a crucial new element in contemporary Indonesia is the emergence of an urban middle class. ${ }^{2}$ The origins of this class can be traced back on the one hand to the civil servants and intelligentsia who were the product of liberalized higher education in the late colonial period and, on the other hand, to the much older groups of Muslim and Chinese traders. The achievement of national independence in 1949 marked the first stage in the consolidation of this new class. After the hiatus of "Guided Democracy" (1959-65), the second stage began with the establishment of the "New Order" government in 1966. The restoration of political stability and the unprecedented prosperity of the oil boom of the 1970s has enabled this middle class to flourish.

1. This article has been written in fits and starts over about three years and mainly while I have been a Visitor in the Department of Economics, Research School of Pacific Studies at the Australian National University. For comments on earlier drafts I am most grateful to Anne Booth, Chris Manning, Peter McCawley, David Penny, Tony Reid, and Thee Kian Wie. I have also benefited from the very stimulating discussion which followed my presentation of a seminar on this topic for the Centre of Southeast Asian Studies at Monash University in April 1982, and from the fair and constructive criticisms of the referees.

2. This was an issue of great interest (at least to foreigners) in the early years of independence, when it was still expected that Indonesia would evolve as a liberal democracy. It was the focus of the classic monograph by Robert van Niel, The Emergence of the Modern Indonesian Elite (The Hague: van Hoeve, 1960) as well as J. M. van der Kroef, Indonesia in the Modern World, 2 vols. (Jakarta: Masa Baru, 1954 and 1957). Since then the focus on the "elite" seems to have blinded social seientists to its middle-class nature. A rare exception is Dan Lev in his studies of Indonesian lawyers, for example "Origins of the Indonesian Advocacy," Indonesia 21 (April 1976): 135-70 (esp. pp. 160-64). J. A. C. Mackie, "Indonesia since 1945: Problems of Interpretation" in Contemporary Indonesia: Political Dimensions (Clayton, Vic.: Monash University, 1979) recognizes the importance of the middle class but refers to it only in passing. 
It is remarkable that no analysis of the New Order has yet taken account of this phenomenon.

One important consequence of the consolidation of a middle class has been a changing concept of what constitutes equity. In precolonial Java the people claimed, and rulers acknowledged, a right to an adequate subsistence. In other words, the primary concern was with absolute poverty. This was also at the root of the Ethical Policy in the late colonial period. The emergence of a nascent Indonesian middle class was accompanied by an intellectual commitment to socialism and equality, which later became the ideological basis of "Guided Democracy." In other words, the emphasis shifted to a concern with relative inequality. Although the New Order government has looked with disfavor upon socialism, under popular pressure it adopted a commitment to equality (pemerataan) as a state objective which was written into the Third Five Year Plan (Repelita III, 1979-84). The new fashion of "Basic Needs" now espoused by international agencies such as the World Bank, however, harks back to the traditional ideal of an adequate subsistence. Thus, not only is there a lively debate both internationally and within Indonesia over development and equity, but also the interpretation of equity is itself in a state of flux.

This article is an attempt to explore the relationship between the rise of a middle class and the changing concept of equity, and its relevance to economic policy. The first section considers the interpretation of the term "middle class." This is followed by an extended discussion of the concept of equity in precolonial Java. The three succeeding sections review the link between equity goals and economic policy in the twentieth century: first under the Ethical Policy of the late colonial period (1901-42); then after independence and during the subsequent period of Guided Democracy (1959-65); and finally under the New Order. The conclusion draws out some implications of the analysis.

\section{The Middle Class}

The term "middle class" means different things to different people. As the term is of European origin, its usage in this article may be clarified by some brief reference to that context. In feudal European society, which was predominantly rural, there was no middle class. Apart from the Church, there was only a land-holding upper class and the common people. A monied class of traders and artisans, whose wealth was derived from commerce rather than land, existed outside feudal society, as reflected in the French word "bourgeois" (townsman). 3 Marx borrowed the term "bourgeoisie," with its connotations of money and wealth, to denote the owners of the means of production. He was thereby able to define mature capitalist society, like feudal society, as having only two basic classes. Feudal society was polarized between those who held land and those who did not, whereas capitalist society, according to Marx, was polarized between those who owned the means of production and those who did not. By this intellectual sleight there was, in theory, still no middle class. The term "middle class" can be used with its commonsense English, Dutch, or German meaning, however, to identify a group distinct from either an upper class of feudal origin, holding power and wealth by virtue of birth, or a lower class of peasants and workers, lacking power, wealth, and even education. This middle class has education, some wealth, and whatever

3. Henri Pirenne, Medieval Cities: Their Origins and the Revival of Trade, trans. Frank D. Halsey (Princeton: Princeton University Press, 1948) is still an excellent discussion of this point. 
Table 1. Average Monthly Expenditure by Main Categories, Urban Jave (1978)

\begin{tabular}{|c|c|c|c|c|c|c|c|c|c|c|}
\hline \multirow[b]{2}{*}{ Expenditure } & \multicolumn{10}{|c|}{ Expenditure Group (Rp/month) } \\
\hline & $\leq 2,000$ & $2-2,999$ & $3-3,999$ & $4-4,999$ & $5-5,999$ & $6-7,999$ & $8-9,999$ & $10-14,999$ & $\geq 15,000$ & Av. \\
\hline Item & 2.1 & 7.5 & 12.2 & 9.3 & 9.7 & 16.6 & 10.5 & 15.5 & 16.6 & $100 \%$ \\
\hline Basic Starches ${ }^{8}$ & 775 & 1,048 & 1,211 & 1,265 & 1,317 & 1,362 & 1,398 & 1,495 & 1,679 & 1,370 \\
\hline Other Food ${ }^{b}$ & 486 & 932 & 1,396 & 1.881 & 2,422 & 3,144 & 4,058 & 5,299 & 9,338 & 3,982 \\
\hline Clothing & 33 & 67 & 122 & 184 & 215 & 297 & 382 & 526 & 1,139 & 419 \\
\hline Housing ${ }^{c}$ & 245 & 367 & 534 & 781 & 973 & 1,276 & 1,778 & 2,621 & 8,138 & 2,423 \\
\hline Taxes \& Insurance & 7 & 17 & 25 & 35 & 59 & 81 & 125 & 223 & 658 & 184 \\
\hline Other & 69 & 122 & 230 & 377 & 485 & 815 & 1,163 & 1,957 & 6,388 & 1,744 \\
\hline Total [Non-food] & 354 & 573 & 911 & 1,377 & 1,732 & 2,469 & 3,448 & 5,327 & 16,323 & 4,770 \\
\hline TOTAL & 1,615 & 2,553 & 3,518 & 4,523 & 5,471 & 6,975 & 8,904 & 12.121 & 27,340 & 10,122 \\
\hline
\end{tabular}

a. Includes cassava.

b. Includes bevereges, cigarettes.

c. Includes fuel, light, and water.

SOURCE: Bi ro Pusat Statistik, Suryey SosiaLEkonomi Nasionah: Tahap Ke-ling (Jakarta, 1978). 
power it has been able to win from the aristocracy. In all three respects, however, the definition of the middle class is a residual one. Where the middle class can be identified sui generis is in terms of lifestyles and values. These are best described, unpejoratively and with an urban connotation, as "bourgeois." In this regard it is still meaningful to talk of a middle class, even though in most Western democracies (including Japan) it has absorbed the upper class, stripped of its power and economic privileges, and ceased to be "middle" in any strict sense.

Although it has often been said that in Indonesia there is no middle class but only a wealthy elite on the one hand and a poverty-stricken mass on the other, this is too simple a view. The new Indonesian elite is a middle-class/bourgeois elite. There is no longer an upper class. The hereditary aristocracy has ceased to be of any consequence. Although the leaders of the Armed Forces have sought in the doctrine of $d w i$ fungsi (dual function) to legitimize their position as trustees for, and natural rulers of, the people, they hardly constitute a new upper class. Reform of the Armed Forces along rational bureaucratic lines, with entrance to the officer corps at least partly on the basis of educational performance, has ensured that Armed Forces officers will remain closely tied to the middle class and not in the foreseeable future become a hereditary caste. The extravagant lifestyles of leaders of the Armed Forces, far from being aristocratic, are typically nouveau riche, displaying to the point of caricature the material aspirations of the middle class. Their conspicuous consumption is unsoftened by any trace of noblesse oblige. In terms of occupation and status, wealth and power, the Indonesian middle class is amorphous: civil servants (including teachers and academics), professionals such as engineers, doctors, lawyers, journalists, airline pilots, and business executives, other "white collar" workers, and, of course, employers. Lifestyle and attitudes, however, provide the underlying coherence of an urban middle-class culture. It is most evident in Jakarta but, being diffused throughout the country by the powerful media of education, television, and magazines, is becoming the national culture.

With regard to material lifestyles, some indication of the size of the middle class can be gained from the expenditure data in Table 1. Definitely middle class are the 16.6 percent of individuals in urban Java whose expenditures in 1978 were greater than Rp 15,000 per month. The distribution of their expenditure is also revealing. While their expenditure on staple starches was not markedly above average, it was very much higher in the case of "other food" (i.e., including "luxury" items such as meat, cheese, and alcoholic beverages), housing, and "other" (i.e., mainly consumer durables). That the middle class is an essentially urban phenomenon is shown by the fact that only 1.1 percent of those in rural areas had expenditures greater than $R p$ 15,000, and much of this was probably accounted for not by rich farmers but by the spillover of urban-based activity into rural zones. 4

The importance of consumer durables in the expenditure patterns of the urban middle class is supported by data on ownership of consumption assets. Based on the careful tabulations of Roger Downey, Table 2 shows the access of those in urban areas by socioeconomic category to the most valuable consumer items--cars, motorcycles, television sets, stereo sets, and refrigerators.

4. This is apparent from the work of Roger Downey, who has classified "rural" dwellers by socioeconomic category: "Indonesian Inequality" (PhD dissertation, Cornell University, 1983). 
Table 2. Access to Major Consumer Durables by Socioeconomic Group (Urban)

(Percentage of individuals with regular access]

\begin{tabular}{lccccc}
\hline & Car & Motorcycle & TV & Refrig & Stereo \\
\hline Self-emp Loyed professionals & 17.2 & 22.6 & 34.1 & 17.9 & 14.3 \\
Menagers and Supervisors & 15.4 & 36.6 & 37.7 & 16.7 & 13.2 \\
Military & 13.7 & 37.9 & 36.4 & 12.2 & 9.3 \\
Professionals (non-teachers) & 12.2 & 34.8 & 36.9 & 15.3 & 11.9 \\
Employers & 12.1 & 27.7 & 31.2 & 14.7 & 9.9 \\
Teachers & 5.9 & 32.6 & 23.1 & 7.6 & 7.1 \\
Higher Clerical and Sales & 5.7 & 29.5 & 30.3 & 9.2 & 8.7 \\
Other Self-employed & 2.9 & 9.3 & 9.8 & 3.2 & 2.8 \\
Other Clerical and Sales & 1.8 & 9.7 & 10.5 & 3.0 & 3.1 \\
Manual Workers & 1.3 & 5.8 & 7.1 & 1.6 & 2.0 \\
\hline
\end{tabular}

SOURCE: Roger Downey, "Indonesian Inequality" (PhD dissertation, Cornell University, 1983 ).

As might be expected, self-employed professionals, managers and supervisors, military, professionals (excluding teachers), employers, teachers, and higher clerical and sales personnel all have much better access to these goods than other self-employed (petty traders, etc.), lower clerical, sales and service personnel, and, especially, manual workers, even though some individuals in the latter categories earned sufficient income to appear to be on the fringe of the middle class. By contrast, only the tiny group of farmers owning more than 5 hectares had a level of access to consumer durables approaching even that of manual workers in urban areas.

Membership of the middle class is not, however, just a matter of levels of income and expenditure. It is sharply defined by social behavior, reflecting what may be described as the privatization of the means of consumption. This is readily apparent from the contrast between middle-class and kampung society. ${ }^{5}$ In the latter, the urban society of the common people, consumption assets such as transistors, bicycles, and crockery are shared ("borrowed"), as well as money, and are to some extent communal property. A refusal to lend something is regarded as antisocial. Houses are left open to anyone who wants to drop in or walk through. What one has is a matter of common knowledge. It is the social pressure to share possessions, as well as the lack of privacy, that tends to drive the more prosperous out of the kampung, either physically or socially. - Their houses are likely to face away from the kampung onto

5. Good descriptions of kampung society are John Sullivan, Back All ey Neighbourhood: Kampung as Urban Community in Yogyakarta, Working Paper No. 22 (Clayton, Vic.: Centre of Southeast Asian Studies, Monash University, 1980), and Patrick Guinness, "Rukun Kampung: Social Relations in Urban Yogyakarta" (PhD dissertation, Australian National University, 1981).

6. Sullivan, Back Alley Neighbourhood, refers to the distinction between those who are "in" and those who are "of" the kampung. 
the street and the amorphous outside world. In order to establish and defend their exclusive access to the goods they have purchased, their doors are likely to be locked and their windows barred. ' Once a family has fled the orbit of kampung society, the only constraint upon its level of consumption is its own income, and the ever-present threat of theft. The essential selfishness of middle-class consumption also stands out in comparison with the old aristocracy: there is no acknowledgment of noblesse oblige.

To avoid the many ambiguities of the terms "middle class" and "bourgeois" it might therefore be less confusing to refer instead to a "consumer class." If the term were understood to refer not to the essential consumption of necessities, which is common to all, but the inessential/excess/luxury consumption which is enjoyed only by the economically privileged, then it would be both specific and workable. To the extent that lifestyles can be quantified in terms of expenditure data and the ownership of consumption assets, it would also be measurable. But, as the rest of this article is concerned to argue, values also matter. It is more meaningful to speak of values and attitudes which are bourgeois or middle class than "consumer class." I shall therefore willfully persist in using the former, but according to common usage and not as precise social science terms.

\section{Equity in Traditional Java}

The kingdoms of precolonial Java such as Majapahit and Mataram have aptly been described as "agrarian empires." " Their economic base was wet-rice agriculture. Technology was premodern but, nevertheless, highly productive. With sufficient land, irrigation, and water buffalo, but without improved seeds or fertilizers, an average family could produce each year up to 2 tons of milled rice equivalent, including the supplementary produce of the house garden." In theory, they could surrender almost half of the rice harvest in taxes and still be provided with an adequate subsistence. The economy was therefore able to generate an economic surplus to support a large ruling class. In the absence of technical progress, however, the tax base could be increased only by proportionate increases in inputs of land and labor. Good virgin land was plentiful. Labor would seem to have been the scarce factor of production. One of the major aims of statecraft was therefore to maximize the size of the population under a ruler's jurisdiction. New settlement and irrigation works were important means to this end. A wise ruler thereby increased his tax base in the form both of corvée labor and of rice. From these flowed the splendor of his court and the might of his army.10

7. Guinness, "Rukun Kampung," offers a good insight into the tensions between the kampung dwellers (orang kampung) and those better-off people whose houses face onto the street (orang pinggir jalan).

8. This concept can be traced back, via Wittfogel and Weber, to Marx's "Asiatic mode of production." Marian Sawyer, Marxism and the Question of the Asiatic Mode of Production (The Hague: Nijhoff, 1977) is a good recent historiography.

9. David H. Penny, "Some Aspects of the Problem of Overpopulation in Rural Java" (mimeo, 1973) and Anne Booth, "Accommodating a Growing Population in Javanese Agriculture," Seminar Paper (Research School of Pacific Studies, Australian National University, March 1983).

10. Soemarsaid Moertono, State and Statecraft in Old Java (Ithaca: Cornell Modern Indonesia Project, 1973) is the best study of government in traditional Java, applying specifically to the Mataram period. 
In such a society, equity was the fundamental "economic" problem. The level of output was determined primarily by the extent of wet-rice agriculture, which, in turn, was determined by the size of the population. Apart from some trade, the economic base was narrow and technology almost static, so that the allocation of resources was straightforward. There was scope for growth in the size of the economy, but not in output per capita.11 The distribution of output, however, was complex. It can best be understood in two stages. The first stage was the division of output between surplus and subsistence, which corresponded to the basic social distinction between rulers (wong gede) and ruled (wong cilik). This involves what has been referred to by Scott as the "moral economy" of the peasant. 12 Scott argues compellingly that the maintenance of some minimum satisfactory level of subsistence is the basis of peasants' behavior and their attitude toward the ruling class. The limitation of his argument is that he never goes beyond subsistence as a concept to specify, from the peasant viewpoint, some standard of livelihood. As far as Scott is concerned, subsistence is what it is. If the level of subsistence cannot be specified then neither can the size of the economic surplus. It is suggested below that, in the case of Java at least, there is a way out of this impasse. Once a surplus has been extracted, the second stage of the process is its distribution among members of the ruling class. This involves the workings of what Weber called the "patrimonial state."

Javanese peasants have a fairly precise ideal of what constitutes an adequate subsistence. Their term is cukupan, which literally translated means "enough." David Penny and Masri Singarimbun, the first authors to have attempted to apply the concept in economic analysis, argue that cukupan represents a real income of 1200 kilograms of milled rice equivalent per family per year. ${ }^{13}$ This is sufficient for a family of two adults and three children to eat rice all year round with a few side dishes, to be simply but respectably dressed on formal occasions, to be simply housed by modest village standards, and to be able to save a small amount for security and to cover future life-cycle ceremonies. "Cukupan" encompasses but transcends the basic biological requirements to sustain life. About half of this quantity of milled rice equivalent would be required to feed a family of five people at the rate of 120 kilograms per person per year, which would provide about 75 percent of minimum daily requirements of 1600 calories. Although the large part of the balance of 1200 kilograms of milled rice equivalent is surplus in strictly nutritional terms, it is not surplus in social terms. Being respectably clothed on formal occasions, living in a proper house, and thereby being able to hold and participate in the life-cycle ceremonies which mark the tempo of village life are not luxuries, but basic to man's identity as a social being. The third element of the concept of cukupan is a sufficient margin to provide security against the inevitable,

11. See Booth, "Accommodating a Growing Population," for a discussion of "static expansion" in the late nineteenth and early twentieth centuries. There is no reason to believe that the situation was any different in earlier periods.

12. James C. Scott, The Moral Economy of the Peasant (New Haven: Yale University Press, 1976). His argument draws upon the substantial literature of peasant economics, of which Alexander V. Chayanov, The Theory of Peasant Economy, ed. Daniel Thorner, Basile Kerblay, and R. B. F. Smith (Homewood, Ill.: Irwin, 1966) has been particularly influential.

13. David H. Penny and Masri Singarimbun, Population and Poverty in Rural Java (Ithaca: N.Y. State College of Agriculture, Cornell University, 1973). 
but unpredictable, fluctuations in harvests. Scott has documented for Burma and Vietnam, and there is ample evidence from elsewhere in Asia, the vulnerability of the peasantry when such insurance can no longer be provided from its own resources. In Java, where harvests are fairly reliable, the margin for insurance seems to have been fairly small. The importance of the concept of cukupan is not that peasants recognize food, social life, and security as basic to man's existence, but that they can specify quite closely the minimum level of real income which enables those needs to be met.

Penny and Singarimbun argue that the meaning given to cukupan has not changed for a long time. There has been no "revolution of rising expectations":

The real level of living implied has not changed with the advent of roads and railways, which opened new market opportunities last century; with the arrival of modern irrigation, from early in the twentieth century; or following the arrival of good rice seeds, fertilizer and pesticides, which started in the 1930s and which have been pushed quite hard since the mid 1950s and particularly since 1968 in the so-called Green Revolution, 14

Moreover, while the concept of cukupan predates the market economy, far from turning the concept into an anachronism, the evolution of the market economy has in fact strengthened it. In the loose translation of cukupan as an "adequate subsistence," the emphasis falls as much upon "subsistence" as upon "adequate." The vital importance of owning enough land to provide 1200 kilograms of milled rice equivalent per annum is that a peasant is thereby not dependent upon the market to gain a livelihood. While he may participate in the market economy as a means of supplementing his income by the exchange of surplus production, this participation is at his own discretion. The market is his vent for the surplus, which is his cushion against hard times. Those who do not have enough land to provide an adequate subsistence, however, are forced to participate in the market economy. They may exchange superior foods such as rice, fruit, eggs, or chickens for inferior carbohydrates such as maize or cassava; they may engage in less productive income-earning activities, such as foraging for grass or firewood or making coconut sugar; they may become wage laborers or migrate to the cities. In colonial times taxes were imposed upon the rural population to create an artificial scarcity that would compel the release for the market of land and labor and their produce. The experience of the rural Javanese has therefore inclined them to view the market with grave suspicion and to see their participation not as a means to greater prosperity but as both consequence and cause of their poverty. As Penny and Singarimbun have shown by cross-sectional analysis of one Javanese village, participation in the market economy is greatest for farmers with little or no land, or for farmers who have more than enough land to be cukupan. Those who have just enough land to be self-sufficient try to remain independent of the market. 13

While the standard of cukupan has not been inflated by rising expectations, neither has it been eroded by worsening poverty. In the 1960s, when food

14. Penny and Singarimbun, Population and Poverty, p. 3. This may, however, be becoming less true. Since the late 1970s a "revolution of rising expectations" does seem to have reached village Java.

15. Ibid. See also David H. Penny and M. Ginting, "House Gardens: A Last Resort?" in Indonesia: Dualism, Growth and Poverty, ed, Ross Garnaut and Peter McCawley (Canberra: Australian National University, 1980), esp. pp. 492-93. This also may be becoming less true. (See note 14 above.) 
crop yields stagnated in the face of a faster than 2 percent annual increase in population, there was rural poverty unprecedented but for the harsh interlude of the Japanese occupation. Napitupulu coined the term "invisible hunger" to describe the malnutrition which had become chronic in much of rural Java. ${ }^{16}$ Based on fieldwork carried out in 1969, Penny and Singarimbun documented the stark reality of poverty at the village level.1' Yet, while poor villagers cut to the bone the real income upon which they could survive, they appear not to have compromised their ideal of what constituted an adequate subsistence. The tenacity of the ideal attests that it is rooted in a concept of equity which is historically based. It is a standard which the common people regard as having obtained in former times and one to which legitimately they can still aspire.

On its own, however, an adequate subsistence is only half a concept. Its logical complement is economic surplus, the balance of output after basic needs have been satisfied. 1. The nature and origins of economic surplus can best be understood by comparison between the productivity of agriculture on the frontier and in the heartland. The frontier is defined by two main characteristics. First, there is a large supply of uncultivated land. Second, no supravillage government has effective authority to impose significant taxes upon the output. These conditions applied in parts of Java until well into the nineteenth century, and still apply today in many parts of the Outer Islands. Penny has shown that under such conditions Javanese peasants took up only so much land as required to produce little more than an adequate subsistence $(1200 \mathrm{~kg} / \mathrm{mre})$. 1 9 Without buffalo or irrigation and using unimproved seeds without fertilizer on rainfed fields, the amount of land required is 0.7 hectares of ricefield and 0.3 hectares of house garden to produce $900 \mathrm{~kg}$ and $300 \mathrm{~kg}$ respectively of milled rice equivalent. This also happens to be about the maximum area which a family can cultivate using only hand tools. Under these circumstances peasants produce an adequate subsistence for themselves but no more. Except perhaps for village taxes, there is no economic surplus.

In the heartland of Mataram, however, Moertono has stated that the ruler levied tax on the rice harvest at a nominal rate of 40 percent. 20 Even allowing that the effective rate was probably much less than 40 percent, it would still appear at first sight that the land tax, not to mention the corvee and various other requisitions, must have cut heavily into the real income of the peasantry. 21 The crucial difference between the frontier and the heartland, however, was

16. Napitupulu, "Hunger in Indonesia," Bulletin of Indonesian Economic Studies 9 (February 1968).

17. Penny and Singarimbun, Population and Poverty.

18. The concept of economic surplus was developed by Baran in the Marxist tradition to refer to the difference between potential production and essential consumption. See Paul Baran, The Political Economy of Growth (London: Penguin, 1973).

19. David H. Penny, "The Transition from Subsistence to Commercial Family Farming in North Sumatra" (PhD dissertation, Cornell University, 1964).

20. Moertono, State and Statecraft, p. 14. See also Appendix I.

21. A. van der Kraan, Conquest, Colonialism and Underdevelopment, ASAA Monograph (Singapore: Heinemann, 1980) includes a fascinating study of precolonial and colonial tax systems on the island of Lombok which shows that, before colonial rule, actual rates of land tax were much lower than nominal rates. 
that in the latter irrigation and the use of buffaloes more than doubled the output of wet rice agriculture--although the output of house gardens seems to have remained unchanged. In the heartland, a peasant family using best practice premodern technology, including double-cropping, could produce more than 2000 kilograms of milled rice equivalent per hectare per annum. 22 Rather than being at the expense of the adequate subsistence of the peasantry, the land tax therefore seems to have represented, more or less, the additional production resulting from the provision of irrigation. In other words, the growth in output brought about by state intervention does not seem to have improved the material well being of village society so much as providing the means for the aggrandizement of the state. ${ }^{23}$

With regard to the distribution of economic surplus, Ben Anderson and Harold Crouch have both argued that traditional Java fits the Weberian model of the patrimonial state. ${ }^{24}$ Unlike the situation in the West, where the holders of political power are now expected to derive no greater benefit from of fice than their salary and perquisites, in patrimonial societies a position takes the form of a benefice. The holder is expected to extract personal income to maintain a level of consumption consistent with his status, reflecting in turn his proximity to the source of power. At the same time, he is expected to be generous in gifts to his patron and to distribute largesse among his own clients. No stigma attaches to luxury consumption as such. Nor was there any responsibility to save or invest. The main danger lay in living above one's station, with the consequences attendant upon those guilty of lese majeste. In the often intrigue-ridden courts of traditional Java, this could be a matter of fine judgment. The distribution of economic surplus was therefore both a means of confirming the status hierarchy and a form of competition within it. Far from being regarded as inequitable, inequality was the very essence of the system.

So far the argument has been that in traditional Java the peasantry held to an ideal of an adequate subsistence, and that this absolute standard defined the most that might legitimately be extracted from their output as economic surplus. It remains to consider whether this was a right recognized by rulers and one which was actually enjoyed. Although Scott defines subsistence narrowly in terms only of physical needs, he nevertheless puts the case very succinctly:

The operating assumption of the "right to subsistence" is that all members of the community have a presumptive right to a living so far as village resources will allow. This subsistence claim is morally based on the common notion of a hierarchy of human needs, with the means for physical survival naturally taking priority over all other

22. Penny, "Some Aspects of the Problem of Overpopulation," and Booth, Accommodating a Growing Population.

23. This conclusion is reminiscent of Wittfogel's thesis of China's "hydraulic society." What needs to be determined, however, is the extent to which irrigation was attributable to state rather than village initiative and resources. In the case of Java see N. C. van Setten van der Meer, Sawah Cultivation in Ancient Java (Canberra: Australian National University Press, 1979).

24. Benedict Anderson, "The Idea of Power in Javanese Culture," in Culture and Politics in Indonesia, ed. Claire Holt et al. (Ithaca: Cornell University Press, 1972), and Harold Crouch, "Patrimonialism and Military Rule in Indonesia," World Politics 31, 4 (July 1979). 
claims to village wealth. ... This right is surely the minimal claim that an individual makes on his society and it is perhaps for this reason that it has such moral force. 23

In the case of Java, at least, Anderson would disagree:

Traditional thought clearly did not allow for any form of social contract or conceptualized system of mutual obligations. ... Any such system would have had to admit a formal reciprocity in political relationships fundamentally alien to Javanese thinking.

This very strong statement is later somewhat qualified:

It would nonetheless be a mistake to infer... that there is no inherent sense of obligation and responsibility in the traditional Javanese world-view. But this sense of obligation was and is an obligation to Power itself ... to suppose that the behavior required of the ruler is predicated on the stated or unstated needs of his subjects would be an error. The ruler must behave properly or his Power will ebb and vanish, and with it the good ordering and smoothness of the social system. 26

While in strictly formal terms this may be true, the interpretation is nevertheless based upon a theoretical rather than a practical ruling class view of politics. Scott's general observations are again pertinent:

-.. in all but the most coercive systems of rural class relationships, there is some pattern of reciprocity, some pattern of rights, which peasants claim as the duty of those who control scarce resources. Such normative traditions are reflected in popular conceptions of what constitutes the "good" lord, the just king, the decent landlord. 27

Moertono would seem to confirm that under normal circumstances the relations between rulers and ruled in Java were hardly more coercive than elsewhere. ${ }^{28}$

In Java, as elsewhere, an adequate subsistence seems to have been seen as one of three basic rights. The other two were peace and order, and justice. 29 To talk of these as "rights" is not, of course, to imply that they were necessarily enjoyed. No doubt the contrary was of ten the case. Sunan Amangkurat I (1646-77) is notorious for his lofty disavowal of concern for the welfare of his subjects. 30 He was not, however, regarded as a model Javanese ruler. Peace, justice, and an adequate subsistence were rights in the sense that the common people

25. Scott, Moral Economy, pp. 176-77.

26. Anderson, "Idea of Power," pp. 47, 52.

27. Scott, Moral Economy, p. 181.

28. Moertono, State and Statecraft, ch. 2, esp. pp. 25-26.

29. Justice (keadilan) might be defined as the right for grievances to be heard and dealt with wisely. The common people had access to two institutions, that of nggogol (procession) and that of pepe (sitting in the sun in the square before the palace). See ibid., p. 76.

30. See D. H. Burger, Structural Changes in Javanese Society: The Supra-Village Sphere (Ithaca: Cornell Modern Indonesia Project, 1956), p. 8. 
felt entitled to expect them of a wise and powerful ruler. ${ }^{31}$ If those rights were not respected the people had the option to flee or, in the ultimate extremity, to rebel against unbearable oppression. The former, more in the nature of an individual act, was obviously very common and has been widely reported. As the Dutch found after 1830 in the administration of the Cultivation System, when the burden became too heavy, the people melted away. As long as there still existed in Java good uncultivated land more or less beyond the reach of rulers and taxation, there was some check upon the degree of exploitation. Without irrigation or water buffalo families could, as already explained, still obtain an adequate subsistence from land hacked out of the jungle. The ideal of an adequate subsistence was therefore still accessible, at least for the enterprising.

Peasant revolts were nevertheless a recurrent phenomenon. As Sartono has argued,

The sporadic agrarian uprisings of the past two centuries, all, whatever their stated objectives, expressed a fundamental protest against the existing conditions in rural life. 32

He also argues that there is no reason to believe that revolts have been confined to the colonial era for which records are avaiable. One might expect, however, that revolts would have become more frequent as the nineteenth century wore on, for reasons other than the trauma of colonial rule. Unoccupied land became more scarce and the authority of the colonial government extended relentlessly. By the end of the century the frontier was rapidly disappearing. Land holdings fragmented and output per capita began to fall, while the efficiency of tax collection improved. ${ }^{33}$ As the ideal of an adequate subsistence receded from grasp, at least in more densely populated areas, it would have been surprising if the appeal of messianic leaders had not increased.

The problem, which seems to have become more widespread during the nineteenth century, is, therefore, not that the Javanese and colonial governments taxed away the economic surplus, but that they taxed away more than the economic surplus. In terms of "moral economy," the margin between the actual level of peasant consumption and the level which would have provided an adequate subsistence was not legitimately part of the economic surplus. Extension of the tax base, mainly through more "efficient" administration, to include a part of subsistence income was facilitated by the changing balance of power between rulers and ruled. The peasantry lost their formerly de facto veto power over the distribution of income, and the leverage of the colonial government greatly increased. As economic surplus per capita produced by wet-rice agriculture declined, the state was better able to defend its claims to the output than the peasantry were able to defend their right to an adequate subsistence. ${ }^{34}$

31. Wayang would seem to have played an important part in legitimizing and reinforcing those rights.

32. Sartono Kartodirdjo, "Agrarian Radicalism in Java," in Culture and Politics, p. 72.

33. Van der Kraan, Conquest, Colonialism, gives a clear picture of how this process occurred in Lombok.

34. As Scott (Moral Economy, p. 7) aptly remarks: "The essential question is who stabilizes his income at whose expense." 
The Ethical Policy $(1901-42)^{35}$

Although Dutch colonial rule has been widely condemned as a period of oppression and exploitation, in some important respects the Dutch seem to have acted very much like a traditional Javanese government. Indeed, after 1900 Dutch rule seems, by traditional Javanese standards, to have been quite enlightened. In particular, there was a systematic attempt to uphold the people's basic rights of peace, justice, and an adequate subsistence. Colonial rule remained, of course, fundamentally exploitive. The aim of the Ethical Policy--or Welfare Policy as it later became known--was not to transform the social order but to preserve it. But traditional Javanese government was also exploitive. The common people expected nothing else. For enlightened exploitation they could be grateful.

Peace and order (rust en orde) was undoubtedly the main benefit which the people of Java received from the final century of colonial rule. Precolonial Java was not a peaceful place, and Schrieke has vividly described the destruction wrought by traditional warfare. As Ricklefs has convincingly argued, the Dutch presence in Java was initially destabilizing and probably made internecine warfare more frequent. The bitter Java War of 1825-30 could be attributed directly to colonial policy. 36 After 1830, however, the Pax Neerlandica lasted for more than a century, probably the longest period of continuous peace ever known. This peace was certainly not enforced for the benefit of the people, but they did benefit nonetheless. Perhaps the best reflection of this was the steady growth in population, although in the long run this was to be a mixed blessing.

With regard to justice, heroic efforts were made to codify adat (customary) law as a legal system for the common people. ${ }^{37}$ In the end it turned out to be a blind alley. Because of the stigma that adat law applied to the "natives" as second-class citizens while the colonial elite enjoyed the privileges of Western law, the maintenance of separate legal systems for rulers and ruled did not formally survive independence. Deprived of the formal protection of codified adat law but still without proper access to Western law, the common people have thereby been left to the benevolence of arbitrary authority.

The mainspring of the Ethical Policy was concern with the diminishing welfare (mindere welvaart) of the Javanese people. The "debt of honor" was, in effect,

35. Although much has been written on the Ethical Policy, the literature has been biased towards its politics rather than its economics. Notable exceptions are John S. Furnivall, Netherlands Indies: A Study of Plural Economy (Cambridge: Cambridge University Press, 1939), A. Jonkers, Het Welvaartzorg in Indonesie (The Hague: van Hoeve, 1948), and P. Creutzberg, ed., Het Ekonomisch Beleid in Nederlandsch-Indie, 4 vols. (Groningen: Wolters \& Noordhoff, 1971-75). This last is a mine of source material.

36. B. Schrieke, Ruler and Realm in Early Java: Indonesian Sociological Studies, Part II (The Hague: van Hoeve, 1959), esp. pp. 143-52; Merle C. Ricklefs, Jogjakarta under Sultan Mangkubumi, 1747-1792 (London: Oxford University Press, 1974); and P. B. R. Carey, ed. and trans., Babad Dipanegara. An Account of the Outbreak of the Java War (1825-30) (Kuala Lumpur: Art Printers, 1981).

37. These efforts are identified with the "Leiden School" and the work of Van Vollenhoven in particular. 
to restore to the people the means to an adequate subsistence. ${ }^{3} 3$ Many of the measures taken would have met with the approval of any enlightened Javanese ruler. Irrigation and resettlement (transmigration) were sound physiocratic policies. The Dutch devoted more attention to roads, railways, telegraphs, and post offices, but the strategic advantages to be gained from good communications were at least understood in precolonial Java. Unfortunately, although these measures must have slowed down the decline in living standards, they were not sufficient generally to restore an adequate subsistence. Had such measures been implemented a century earlier when population pressure on the land was less acute, they would no doubt have yielded more favorable results. It was not altogether the fault of the Dutch that Java "filled up" during the course of the nineteenth century, even though the Pax Neerlandica had allowed the population to grow more steadily than would otherwise have been the case. ${ }^{39}$

Despite a similarity of means, however, in conception the Ethical Policy was fundamentally different from a modern Development Policy. There was no objective of a sustained long-term improvement in living standards. As stated above, the main goal was the more modest one of restoring to the peasantry the means to an adequate subsistence. Proclamation of the Ethical Policy amounted to acknowledgment that an adequate subsistence was a basic right. The Dutch did not forgo their claim to the economic surplus, but implicitly recognized that they had expropriated more than the economic surplus and thereby infringed this right of subsistence. The more telling criticism that can be made of the Ethical Policy is not that the Dutch were half-hearted in their efforts to raise agricultural productivity but that they balked at any radical lightening of the tax burden on the people. Anne Booth has shown for the period 1926-39 that, excluding subsistence consumption from the tax base and allowing for some progressivity, the tax burden upon the indigenous population was consistently higher than upon the non-Indonesian population. ${ }^{\circ}$ Moreover, during the Depression of the 1930s, the tax burden upon the indigenous population increased sharply and disproportionately. This criticism merely confirms, however, that the Ethical Policy presupposed a basic social distinction between rulers and ruled. Notwithstanding the liberal origins of the Policy, it reflected a colonial view of equity which coincided remarkably closely with that of

38. The data are not available to establish whether there was in fact a steady decline in the level of welfare in the latter part of the nineteenth century. The Ethical Policy was, however, based on this premise, and the commission of enquiry which produced a series of reports between 1904 and 1914 was known as the Mindere Welvaart Commissie. Summarizing the results of this enquiry in 1914, Hasselman concluded that the level of welfare had declined in some areas of Java but that this was not a general phenomenon. See C. J. Hasselman, "General Survey of the Results of the Investigation into Economic Prosperity in Java and Madura, in Indonesia: Selected Documents on Colonialism and Nationalism, 1830-1941, ed. C. Penders (St. Lucia: Queensland University Press, 1977). The term "debt of honor" was coined by C. T. van Deventer in his famous article, "Een Eereschuld" (1899).

39. See P. McDonald, "A Historical Perspective to Population Growth in Indonesia," Indonesia: The Making of a Culture, ed. J. J. Fox (Canberra: Australian National University, 1980), esp. pp. 84-88.

40. Anne Booth, "The Burden of Taxation in Colonial Indonesia in the Twentieth Century," Journal of Southeast Asian Studies 11, 1 (March 1980). 
traditional Java. To assess the Ethical Policy as a Development Policy is only to show that it was not what it was not.

Education, however, was one critical aspect in which the Ethical Policy was altogether untraditional. In the more recent period with which we are familiar, Javanese rulers never displayed much concern for the formal education of their subjects. Neither for many years did the colonial government. At the end of the nineteenth century, access to Western education was still confined for the most part to the sons of regents, while vernacular education was rudimentary. ${ }^{41}$ The significance of educational reforms under the Ethical Policy was twofold. First, the government accepted responsibility for "native" education in the form of the desa (village) school. Progress towards mass primary education was nevertheless very slow. 42 Second, children of well-to-do Indonesian parents were allowed access to Dutch secondary education, with the opportunity of proceeding to professionally oriented tertiary education in such fields as medicine, law, and engineering. The aim was to produce a small Westernized Indonesian elite whose members could fill responsible positions in the rapidly growing civil service. This enlightened policy rebounded on the Dutch. Contact with Western liberal values made these privileged Indonesians more aware of the discrepancy between Dutch rule in the Netherlands and Dutch rule in the East Indies. At the same time, their limited career prospects highlighted the fact that they were still second-class citizens in their own country. Their frustration became one of the wellsprings of the modern nationalist movement. ${ }^{43}$

\section{Independence and Guided Democracy}

Independence brought about a radical shift in values as the nascent Indonesian middle class displaced the colonial Dutch as holders of political power. As a result of the education policy of the late colonial era, most of the leaders of this nationalist revolution were in the Western liberal tradition. No one has put it more forcefully than J. M. van der Kroef in the early years of independence:

The educated elite of commoners who shaped the Indonesian Revolution and are now at the helm of the state are children of the French Revolution and of nineteenth century Liberalism. They, like their protagonists of 1789 , directed their efforts towards the abolition of privilege, an end to the restrictions that hampered the full

41. The first Javanese schools dated from 1848 and were set up to train children of noble families as scribes and administrators. About the same time schools were set up to train teachers and vaccinators (dokter djawa). See Van Niel, Modern Indonesian Elite, pp. 26-30.

42. Ibid., pp. 68-70.

43. Heather Sutherland, The Making of a Bureaucratic Elite, ASAA Monograph (Singapore: Heinemann, 1979), points out that an early decision was made to exclude Indonesians from the civil service proper (Binnenlands Bestuur). Van Niel, Modern Indonesian Elite (esp. pp. 180-81) refers to the decision not to pay Indonesians the same remuneration as Europeans in services such as education, credit, and irrigation where they worked side by side. John Ingleson, The Road to Exile: The Indonesian Nationalist Movement, 1927-1936, ASAA Monograph (Singapore: Heinemann, 1979) is a good account of the early nationalist movement. 
use of their economic resources, the overthrow of a political system which left them outside the legislative process in their own country and the removal of the social inequality and inhuman exploitation on which the colonial ancien regime rested. 44

It was no coincidence that the government of an independent Indonesia was republican and democratic. In the economic sphere, however, where the Dutch retained their supremacy, liberalism was discredited in favor of socialism. Lance Castles has nicely described the circumstances which gave rise to this situation:

[I]t was from the small circle of the Western-educated, generally springing from the aristocratic and official class, that the leadership of the national movement and the elite of the new state were mainly drawn. In this group an aristocratic contempt for commercial and industrial occupations combined with an intellectual attraction to Marxism to form a strongly anti-capitalist ideology, but one whose positive content differed a good deal from one individual to another. As the commanding heights of the Netherlands Indies economy were already occupied by European capital, nationalist sentiment coincided with socialist in demanding their nationalisation. .... As employees (or potential employees and office-holders) of the state, the elite had every reason to favour the maximisation of its economic role. 4 s

The essence of Sukarno's Marhaenist ideology was that the elite formed a single class with the peasants and workers. In terms of ownership of the means of production, there was no national bourgeoisie. Concern for the welfare of the common people was expressed in the principle of social justice, meaning economic equality, which was enshrined in the Panca Sila (Five Principles) and written into the Constitution. 4

The abandonment of parliamentary democracy in favor of "Guided Democracy" and "Guided Economy" was meant to provide the conditions for realizing the socialist goals of the revolution. In practice, "Socialism à la Indonesia" involved primary emphasis upon state ownership and control. Once Dutch enterprises had been nationalized, however, much of the momentum was lost. The bureaucracy grew until it was quite bloated, but the socialist consensus did not extend as far as effective measures to raise the level of welfare of the people. Under the slogan of sandang-pangan (food and clothing) an attempt was made through officially sponsored cooperatives and rationing to achieve some equality in the distribution of basic commodities, in accordance with the Panca Sila principle of social justice. ${ }^{4}$ Because of widespread corruption and the failure of the cooperatives, however, distribution was implemented only for civil servants, thereby helping to turn the civil service into a vast relief organization.

44. Quoted in Gunnar Myrdal, Asian Drama (New York: Twentieth Century Fund, 1966), pp. 750-51.

45. Lance Castles, "The Fate of the Private Entrepreneur," in Sukarno's Guided Indonesia, ed. T. K. Tan (Brisbane: Jacaranda Press, 1967), p. 74.

46. See Sukarno, "The Pantja Sila" in Indonesian Political Thinking 1945-1965 ed. Herbert Feith and Lance Castles (Ithaca: Cornell University Press, 1970), pp. 40-49.

47. See T. K. Tan, "Sukarnian Economics" in Sukarno's Guided Indonesia, pp. 29-45. 
In theory the people were also meant to benefit from the nationalization of foreign enterprises, through the provision of public sector goods and services at heavily subsidized prices. The impact of subsidies on the budget was so great, however, that this attempt to reconcile state ownership with popular welfare was economically disastrous. The resultant huge budget deficits generated hyperinflation, which had a highly regressive distributional impact, at least in urban areas. $4:$ Anyone with liquid capital and political connections was well placed to make large profits through concessions and speculation--Castles referred to the wry distinction between the newly rich (orang kaya baru) and the suddenly rich (orang kaya mendadak). 4" Those on fixed money incomes were economically annihilated. Even many civil servants faced a struggle to survive as the real value of their salaries and supplements fell more and more below the cost of living. Smallholder exporters, mainly in the Outer Islands, were heavily penalized by the multiple exchange rate regime. Ironically, however, the real income of food producers may have risen, not because of any socialist measures but because they were able to disengage themselves from the market economy.

Although Sukarno saw himself as the symbol of national unity, the brief era of Guided Democracy shattered the social consensus that had more or less held since independence. The rhetoric was socialist but the reality was worsening inequality. At the same time, Sukarno's patronage of the Communist party (PKI) provided a hitherto unparalleled opportunity for radical mobilization of the landless peasantry. ${ }^{30}$ By the mid-1960s there was the real possibility that the demise of Sukarno would allow the PKI to gain control of the government with the support of the first widespread peasant movement in Indonesian history. This would have been the ultimate vindication of Sukarno's ideal of the continuing revolution, albeit not one that he seems to have contemplated with any enthusiasm.

\section{The New Order}

While the events of September 30/October 1, 1965 may be described in terms of their outcome as a military coup, the establishment of the New Order is perhaps better understood as a middle-class counterrevolution. Indisputably, the PKI and the rural poor were the losers. To what extent the latter would ultimately have benefited from a Communist party victory is perhaps an open question, but the failure of the PKI's bid for power and its bloody extirpation removed all possibility of an organized peasant revolution within the foreseeable future. The Armed Forces were the obvious victors, since their already great de facto authority was formalized by martial law. Somewhat less obviously, an emerging middle class was also to be counted among the winners. Notwithstanding the phenomenal growth in the size of the bureaucracy under Guided Democracy, its members had for the most part suffered a marked decline in living standards,

48. The best study of the nature, causes, and effects of the inflation is J. A. C. Mackie, Problems of the Indonesian Inflation (Ithaca: Cornell Modern Indonesia Project, 1967).

49. Castles, "Fate of the Private Entrepreneur," p. 78.

50. Rex Mortimer, "Strategies of Rural Development in Indonesia: Peasant Mobilisation versus Technological Stimulation," in Stubborn Survivors: Dissenting Essays on Peasants and Third World Development by Rex Mortimer, ed. Herbert Feith and R. Tiffen (Melbourne: Centre of Southeast Asian Studies, Monash University, 1984). 
and their privileges had been further threatened by the power of the PKI. It is no paradox that the students, who in 1966 spearheaded the movement which forced Sukarno to abdicate, were absorbed so easily into the New Order. In 1966 they were not only the conscience of the emerging middle class but also had a strong vested interest in a system of privilege for those with education. Robison, however, offers a very different interpretation:

\begin{abstract}
Before 1959, and even up to 1965, the intellectuals were to a large degree integrated in the power structure through the agency of the mass parties. After 1965, when hegemony was seized by the military, intellectuals ceased to play roles as politicians and were offered only those of technocrats and advisers. . . . Such roles offer little that is attractive to people proud of their technological, administrative and managerial competence. 51
\end{abstract}

Yet this seems to be doubly wrong. First, if one talks of a middle class rather than just intellectuals-and Robison himself defines the intellectuals as a class with civil servants and students-then the mass parties of the Old Order, despite their largely middle-class leadership, posed a serious radical threat to middle-class aspirations. Second, it is hardly self-evident that those "proud of their technological, administrative and managerial competence" would be dissatisfied with the roles of technocrat and adviser as opposed to the impotence of all but a few politicians under the Old Order. Rather than dismissing the inclusion of the technocrats in New Order cabinets as mere window dressing, it seems more helpful to see their role as the logical outcome of the coalition formed in 1966 between the Armed Forces and middle-class elements, $\$ 2$ The economic goals of the New Order, stability and development--meaning in practice economic growth--also reflected this coalition. Socialism was all but disowned.

Under the New Order the material aspirations of the middle class have been achieved beyond the wildest dreams of those who took to the streets in the last few days of the old regime. The rate of inflation was reduced from about 600 percent in 1965-66 to 10 percent in 1969." 3 Due largely to the booming oil sector, which accounted for the major proportion of both the value of exports and of central government revenues, between 1970 and 1980 the economy maintained a remarkable average growth rate of about 8 percent in real terms. Even allowing for a population growth rate of about 2 percent, this has meant an impressive rise in real income per capita. The benefits have flowed disproportionately to the relatively small urban middle-class elite. Between 1960 and 1976 real expenditure per capita increased twice as rapidly in urban (40 percent) as in rural (20 percent) Java, and faster in Jakarta (50 percent) than in any other city. Moreover, the increase of 40 percent in urban per capita expenditures was biased heavily toward the upper expenditure quintiles, 34

51. Richard Robison, "Towards a Class Analysis of the Indonesian Military Bureaucratic State," Indonesia 25 (April 1979): 39.

52. This is not to deny, of course, that middle-class intellectuals belonged to the PKI and PNI and were among the victims when these parties were suppressed. There was certainly no monolithic middle class.

53. S. A. Grenville, "Monetary Policy and the Formal Financial Sector," in Garnaut and McCawley, Indonesia: Dualism, p. 108.

54. See R. M. Sundrum and Anne Booth, "Income Distribution in Indonesia: Trends and Determinants," in ibid. 
Observation confirms the pattern suggested by the expenditure data. The number of motor vehicles available for personal use-whether privately or government owned--has soared, and the number of motorcycles has increased even more dramatically. Middle-class youths are now ashamed to ride a bicycle. Those, who at the beginning of the New Order would already have been counted as part of the middle class, have been able to extend their homes or move into modern new housing complexes. The modest furnishings of the late 1960s have given way to much greater luxury, and the range of typical household appliances has increased to include television, stereo sets, air conditioners, refrigerators, and rice cookers-and now videocassette recorders. One notices a fashion for collecting rare birds and fish. Other signs of middle-class prosperity are the proliferation of hair salons (for both sexes), the preference for expensive hand-painted batik clothing, the wearing of imported luxury watches, and the greater frequency of overseas travel. In view of the ready availability of servants, many middle-class families, let alone those belonging to the military elite, are now able to enjoy a standard of living which would be regarded as luxurious by Western middle-class standards.

This consumer revolution has involved a good deal of superficial Westernization, sometimes referred to as the spread of "Coca-Cola culture." The press, radio, films, and, more recently, television, have been powerful influences. Being seen to be moderen, how ever, has been an important aspect of the culture of the Indonesian elite since the late colonial period. In the mestizo colonial culture that prevailed until the mid-nineteenth century, the largely male European community tended to emulate the lifestyles of the Javanese aristocracy. With the opening up of Java to private capital and the consolidation of a more European middle-class society in the late nineteenth century, a model was set for the lifestyle of the Indonesian middle class which emerged with the liberalization of secondary and tertiary education. After independence and the expulsion of Dutch nationals in 1958, middle-class Indonesians simply took their place, occupying their homes and taking over their less portable possessions. Under the New Order there have been widening opportunities for middle-class Indonesians to mix professionally and socially with middle-class Westerners, both within and outside the country. This has been reflected in the sustained demand for English-language conversation courses. Some convergence of Indonesian middle-class lifestyles with those of the West is therefore hardly surprising.

Although Western consumer preferences have been absorbed more easily than Western middle-class values, in the latter case there would also seem to be some convergence. First, the Indonesian middle class has come to accept both the desirability and the possibility of steadily rising living standards. The commitment to development as a national priority in the early days of the New Order was a conscious break with the traditionally static perception of the economy which had been pervasive in the period of Guided Democracy. Second, far from being accepted as part of the natural order of society, inequality is increasingly being viewed as undesirable per se, as seen in the inclusion of "equality" (pemerataan) among the goals, however vague, of the Third Five Year Plan (1979-84). ss Third, the middle class does not subscribe to the

55. Repelita III specified eight paths to equality (jalur pemerataan) namely:

1. Equality in fulfilling people's basic needs, especially for food, clothing, and shelter.

2. Equality of opportunity in obtaining education and health services. 
feudal idea that each man is born to his station in life, but rather aspires to upward mobility on the basis of education and experience. The notions of merit and career, which are quintessentially middle class, are epitomized in the bureaucracies of the civil service, armed forces, and business corporations. Whether the Indonesian middle class also displays the traditional Western middle-class "virtues" of hard work and thrift is another question. Fourth, elements of the middle class are displaying a growing concern with liberal ideas of democracy, the rule of law, and freedom of speech. 36 They are also more and more inclined to perceive corruption as a moral issue.

The middle-class commitment to rising living standards, equality, social mobility, and democratic rights does not mean, however, that these are necessarily to be enjoyed by all. Rather it seems that, as in George Orwell's familiar phrase, some are to be more equal than others. The substance of the middle-class commitment to equality can best be understood in relation to the slogan of pola kehidupan sederhana (modest lifestyles). It is officially regarded as extravagant to own more than one bungalow, to have more than one car, and to make frequent trips abroad. No one is to be condemned, however, for having only one modern bungalow fitted out with such items as air conditioning, carpets, refrigerator, color television, and sound system, for having only one car and motorcycles for the children, or for making occasional trips abroad. These are now the "basic needs" of the middle class. It is trite to point out that, by contrast, few villagers or kampung dwellers have access to electricity, let alone being able to afford such expensive consumer durables. For many it is still a struggle to eat properly all year round, to buy medicines if they fall sick, and to support their children through the nominally free state education system. Yet the proposition has never seriously been put forward that genuine equality and implementation of pola kehidupan sederhana should involve the urban middle class forgoing all but an adequate subsistence until such time as all other Indonesians are as well off. The real target of the slogan would seem to be not the middle class but a small elite. In terms of middle-class values, the lavish conspicuous consumption of high civil and military officials, far from being legitimized-as would traditionally have been the case--by proximity to the source of political power, is regarded as an abuse. This moral condemnation seems to be more closely allied to jealousy and envy, however, than to any genuine concern for the welfare of the common people.

The New Order government has nevertheless taken measures to raise the level of popular welfare. First and foremost, there is the rice buffer stock and price stabilization scheme operated since the mid-1960s by Bulog (Badan

3. Equality of income distribution.

4. Equality of employment opportunities.

5. Equality of business opportunities.

6. Equality of opportunity to participate in development, especially for the young generation and women.

7. Equality in the spread of development throughout the whole country.

8. Equal opportunity in obtaining justice.

These are broad goals, however, without specific guidance as to how they are to be achieved.

56. See especially Lev, "Origins of Indonesian Advocacy," p. 160, and also J. A. C. Mackie, "Indonesia Since 1945--Problems of Interpretation," in Interpreting Indonesian Politics, ed. Benedict Anderson and Audrey Kahin (Ithaca: Cornell Modern Indonesia Project, 1982), p. 129. 
Urusan Logistik), the Logistics Affairs Agency. 57 This has very effectively cushioned consumers against large price rises due to harvest failure. Because Bulog's policies work through the market for rice, however, they do not provide a means of supplementing the subsistence of people who are so poor that they lack the purchasing power to buy sufficient rice. Only very occasionally, in the case of localized outbreaks of severe famine, has rice been distributed on the basis of need. The same applies to policies to stabilize the prices of other of the nine basic commodities (bahan pokok)--salted fish, cooking oil, sugar, salt, kerosene, soap, and low-grade textiles. ${ }^{3}$ In the case of kerosene there has been a very large subsidy, so while in many cities there has also been a considerable subsidy of public transport bus fares. While all of these subsidies have helped to reduce the cost of living, the distribution of benefits has been biased in two ways. First, the benefits have flowed disproportionately to those living in the large cities--there are good political reasons why the government should fear urban "rice riots." Second, because the amount of subsidy received is proportional to the amount of the good consumed, much of the benefit of consumer subsidies has flowed to the urban middle class. The urban middle class have also tended to be the prime beneficiaries of government housing programs, which had been directed mainly towards the needs of civil servants and, perhaps to a lesser extent, of clinics set up under the family planning and health programs. Although the New Order government might appear to be pursuing the elements of a "basic needs" strategy, overall there seems to be little evidence of redistribution away from the urban middle class.

One way of pursuing equality without any redistribution of wealth and income is to redefine equality in terms of equality of opportunity. The opportunity is for the poor peasant or coolie to rise up into the middle class. The means to that end is education, to which the New Order government has now given top priority. In the 1982-83 development budget, education was the largest single item. This expenditure is directed toward ultimately achieving universal primary education, as well as toward a big expansion in junior high school enrollments. In itself this is almost certainly a good thing. It does not follow, however, that the outcome will indeed be equality of opportunity. First, in the absence of positive discrimination, poor parents cannot afford to support their children as dependents through six years of higher education, even if they could afford the outlays for books, uniforms, and excursions, the unofficial entrance fees, and the variety of other legal and illegal levies. Second, it is the old fallacy of misplaced aggregation to assume that, because education allows some individuals to become upwardly mobile, it will therefore allow a whole lower class to seize a very limited range of employment opportunities. Nevertheless, historically education has been the main channel of upward mobility, and income is still highly correlated with the level of education.60 The argument is therefore sufficiently plausible and the grounds for believing it so appealing, that peasant and working-class parents may well aspire to middle-class materialism for their children, rather than seek to overthrow middle-class rule for a

57. See Leon A. Mears and Sidik Moeljono, "Food Policy," in The Indonesian Economy during the Soeharto Era, ed. Anne Booth and Peter MeCawley (London: Oxford University Press, 1981).

58. These are basically the sandang-pangan commodities of the Sukarno period.

59. See Howard Dick, "The Oil Price Subsidy, Deforestation and Equity," Bulletin of Indonesian Economic Studies 16, 3 (November 1980).

60. See Sundrum and Booth, "Income Distribution in Indonesia." 
socialist ideal of genuine equality. On the other hand, there is clear evidence that the rate of open unemployment is highly correlated with the level of education, and the rate can be expected to worsen as educational opportunities widen. This problem has already given rise to political tensions in some other developing countries, most notably Sri Lanka. It would be ironic if, by the rapid development of education, the New Order were to sow the seeds of its own destruction at the hands of discontented middle-class youth. 12

\section{Conclusion}

The middle-class revolution that began in Indonesia in the 1920 s may yet be a victory for bourgeois democracy, but this could be little cause for rejoicing on the part of the people. The post-independence history of India-and, until martial law, of the Philippines--shows how unresponsive a prosperous middle-class democracy can be to mass poverty. 62 Paradoxically, the smaller the threat of popular revolution, the more favorable are the conditions for the emergence of middle-class democracy from military rule, but the weaker the pressures for any significant redistribution of wealth and income at the expense of the middle class. Although a growing concern for equality may be expressed more and more in Western middle-class terms, in practice the common people are unlikely to be the beneficiaries. Relative inequality can be expected to increase as economic growth increases the size of the economic surplus distributed among the middle class. Absolute poverty could also worsen if an emerging rural elite of rich farmers and of absentee landlords were to introduce modern capital-intensive farm technology and thereby displace labor at a faster rate than can be absorbed in manufacturing, construction, or services.

In terms of development policy, there seems to be a great historical irony. Since the mid-1970s the Western concern with Third World poverty has at last been translated into human terms in the form of a "basic needs" strategy for economic development. In Indonesia this ought to correspond very closely with the traditional Javanese perception of an adequate subsistence (cukupan). Yet it has struck no resonant chord. The reason would seem to be that the middle class now dominates articulate society, and government no longer acknowledges a popular right to an adequate subsistence. A rhetoric of equality is being translated into some efforts to ensure equality of opportunity and to facilitate upward mobility, but "devil take the hindmost." No general improvement in popular welfare is likely until growth has been sustained for long enough to create a permanent shortage of unskilled rural labor and usher in an era of rising real wages.

61. As argued above, it was probably the most enlightened element of the Ethical Policy, namely the extension of Western liberal education to a small Indonesian elite, that stimulated the nationalist movement and hastened the end of colonial rule.

62. Of course, the Emergency in India and Martial Law in the Philippines do not seem to have had any greater impact upon mass poverty, notwithstanding all the rhetoric. 